\title{
Front Matter: Volume 7114
}

, "Front Matter: Volume 7114," Proc. SPIE 7114, Electro-Optical Remote Sensing, Photonic Technologies, and Applications II, 711401 (30 October 2008); doi: 10.1117/12.816765

SPIE. Event: SPIE Security + Defence, 2008, Cardiff, Wales, United Kingdom 


\title{
PROCEEDINGS OF SPIE
}

\section{Electro-Optical Remote Sensing, Photonic Technologies, and Applications II}

\author{
Gary W. Kamerman \\ Ove K. Steinvall \\ Keith L. Lewis \\ Thomas J. Merlet \\ Richard C. Hollins \\ Editors
}

15-16 September 2008

Cardiff, Wales, United Kingdom

Sponsored by

SPIE Europe

Cooperating Organisations

EMRSDTC-The Electro-Magnetic Remote Sensing Defence Technology Centre

(United Kingdom)

FOl-Swedish Defence Research Agency (Sweden)

Institute of Photonics (United Kingdom)

Luminex Corporation (USA)

Technium OpTIC (United Kingdom)

WOF-Welsh Opto-electronics Forum (United Kingdom)

Published by

SPIE

Volume 7114 
The papers included in this volume were part of the technical conference cited on the cover and title page. Papers were selected and subject to review by the editors and conference program committee. Some conference presentations may not be available for publication. The papers published in these proceedings reflect the work and thoughts of the authors and are published herein as submitted. The publisher is not responsible for the validity of the information or for any outcomes resulting from reliance thereon.

Please use the following format to cite material from this book:

Author(s), "Title of Paper," in Electro-Optical Remote Sensing, Photonic Technologies, and Applications II, edited by Gary W. Kamerman, Ove K. Steinvall, Keith L. Lewis, Thomas J. Merlet, Richard C. Hollins, Proceedings of SPIE Vol. 7114 (SPIE, Bellingham, WA, 2008) Article CID Number.

ISSN 0277-786X

ISBN 9780819473462

Published by

SPIE

P.O. Box 10, Bellingham, Washington $98227-0010$ USA

Telephone +1 3606763290 (Pacific Time) · Fax +1 3606471445

SPIE.org

Copyright (c) 2008, Society of Photo-Optical Instrumentation Engineers

Copying of material in this book for internal or personal use, or for the internal or personal use of specific clients, beyond the fair use provisions granted by the U.S. Copyright Law is authorized by SPIE subject to payment of copying fees. The Transactional Reporting Service base fee for this volume is $\$ 18.00$ per article (or portion thereof), which should be paid directly to the Copyright Clearance Center (CCC), 222 Rosewood Drive, Danvers, MA 01923. Payment may also be made electronically through CCC Online at copyright.com. Other copying for republication, resale, advertising or promotion, or any form of systematic or multiple reproduction of any material in this book is prohibited except with permission in writing from the publisher. The CCC fee code is 0277-786X/08/\$18.00.

Printed in the United States of America.

Publication of record for individual papers is online in the SPIE Digital Library.

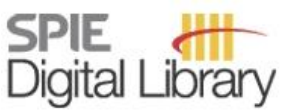

SPIEDigitalLibrary.org

Paper Numbering: Proceedings of SPIE follow an e-First publication model, with papers published first online and then in print and on CD-ROM. Papers are published as they are submitted and meet publication criteria. A unique, consistent, permanent citation identifier (CID) number is assigned to each article at the time of the first publication. Utilization of CIDs allows articles to be fully citable as soon they are published online, and connects the same identifier to all online, print, and electronic versions of the publication. SPIE uses a six-digit CID article numbering system in which:

- The first four digits correspond to the SPIE volume number.

- The last two digits indicate publication order within the volume using a Base 36 numbering system employing both numerals and letters. These two-number sets start with $00,01,02,03,04,05$, 06, 07, 08, 09, OA, OB ... 0Z, followed by 10-1Z, 20-2Z, etc.

The CID number appears on each page of the manuscript. The complete citation is used on the first page, and an abbreviated version on subsequent pages. Numbers in the index correspond to the last two digits of the six-digit CID number. 


\section{Contents}

vi Conference Committee

\section{SESSION 1 PASSIVE SENSING AND DATA PROCESSING}

711402 Automatic detection of small surface targets with electro-optical sensors in a harbor environment [7114-01]

H. Bouma, D.-J. de Lange, S. P. van den Broek, R. A. W. Kemp, P. B. W. Schwering, TNO

Defence, Security and Safety (Netherlands)

711403 Multisensor benchmark data for riot control [7114-02]

U. Jäger, M. Höpken, B. Dürr, J. Metzler, D. Willersinn, Fraunhofer Institute for Information and Data Processing (Germany)

711404 Assessment and optimization of methods for tracking people in riot control scenarios [7114-03]

Y. Hübner, J. Metzler, B. Dürr, U. Jäger, D. Willersinn, Fraunhofer Institute for Information and Data Processing (Germany)

711405 Improved satellite image compression and reconstruction via genetic algorithms [7114-04] B. Babb, F. Moore, Univ. of Alaska Anchorage (United States); M. Peterson, Wright State Univ. (United States); G. Lamont, Air Force Institute of Technology (United States)

711407 System concepts for optical detection of surface laid mines [7114-06]

O. Steinvall, I. Renhorn, D. Letalick, Swedish Defence Research Agency, FOI (Sweden)

SESSION 2 EO SENSING TECHNOLOGIES AND THE EMRS DTC

711408 Temporal resolution enhancement from motion [7114-07]

M. P. Rollason, M. J. A. Strens, A. P. Gardner, QinetiQ Ltd. (United Kingdom)

\section{SESSION 3 LASER SENSING AND SYSTEMS}

7114 OD Mono- and bi-static SWIR range-gated imaging experiments for ground applications (Invited Paper) [7114-12]

E. Repasi, P. Lutzmann, FGAN-FOM, Research Institute for Optronics and Pattern Recognition (Germany); O. Steinvall, M. Elmqvist, FOI-Swedish Defence Research Agency (Sweden)

$71140 \mathrm{OE}$ Wideband dual-frequency lidar-radar for high-resolution ranging, profilometry, and Doppler measurement [7114-13]

G. Pillet, L. Morvan, D. Dolfi, J.-P. Huignard, Thales Research and Technology (France)

7114 OG Helicopter collision avoidance and brown-out recovery with HELLAS [7114-15]

C. Seidel, I. Schwartz, P. Kielhorn, EADS Deutschland GmbH (Germany) 
$7114 \mathrm{OH}$ Discriminating land mines from natural backgrounds by depolarization (Invited Paper)

[7114-16]

F. Stabo-Eeg, Norwegian Univ. of Science and Technology (Norway); D. Letalick,

O. Steinvall, Swedish Defence Research Agency (Sweden); M. Lindgren, Norwegian Univ.

of Science and Technology (Norway)

\section{SESSION 4 PHOTONIC COMPONENTS AND ARCHITECTURES FOR MICROWAVE SYSTEMS AND DISPLAYS}

7114 OK DFB laser diodes and quantum cascade lasers for sensors in safeguard applications [7114-19]

J. Seufert, M. Fischer, M. Legge, K. Roessner, R. Werner, nanoplus Nanosystems and Technologies GmbH (Germany); J. Hildenbrand, J. Herbst, A. Lambrecht, Fraunhofer Institute for Physical Measurement Techniques (Germany); J. Koeth, nanoplus Nanosystems and Technologies GmbH (Germany)

$7114 \mathrm{OL} \quad$ Fully automated E-field measurement setup using pigtailed electro-optic sensors for accurate, vectorial, and reliable remote measurement of high-power microwave signals [7114-20]

M. Bernier, A. Warzecha, L. Duvillaret, IMEP-LAHC, CNRS, Minatec-INPG (France);

J.-L. Lasserre, A. Paupert, DGA, DET, CEG, LDP, CGN, EXC (France)

$71140 \mathrm{M}$ Gallium arsenide linearised electro-optic waveguide modulators for RF-on-fibre applications [71 14-26]

J. M. Heaton, Y. Zhou, H. Gao, G. Murdoch, A. Miller, C. Main, D. Hannan, S. Clements, RFMD (UK) Ltd. (United Kingdom)

$71140 \mathrm{~N}$ Encountering false alarms for detection of point targets in highly cluttered background [7114-32]

R. Saran, H. B. Srivastava, A. Kumar, Instruments Research and Development Establishment (India)

$711400 \quad$ UK photonics in defence and security [7114-23]

C. Gracie, Scottish Optoelectronics Association (United Kingdom); I. Tooley, UK Consortium of Photonics \& Optics (United Kingdom); A. Wilson, Photonics Knowledge Transfer Network (United Kingdom)

$71140 Q \quad H i g h-p o w e r$ single-mode eye-safe wavelength semiconductor lasers [7114-25]

M. L. Osowski, W. Hu, R. M. Lammert, S. W. Oh, P. T. Rudy, R. Boehm, T. Stakelon, L. Vaissie,

J. E. Ungar, QPC Lasers, Inc. (United States)

\section{SESSION 5 POSTER SESSION}

$71140 R \quad$ Algorithm for remote sensing of land surface temperature [7114-27]

S. AlSultan, Qassim Univ. (Saudi Arabia); H. S. Lim, M. Z. MatJafri, K. Abdullah, Univ. Sains Malaysia (Malaysia)

7114 OS Efficient target detection by object-based thematic mapping using remote sensing imagery [7114-28]

X. Jia, Y. Xiao, M. R. Pickering, The Univ. of New South Wales, Australian Defence Force Academy (Australia) 
7114 OT Using visible remotely sensed data for air quality study [7114-29]

H. S. Lim, M. Z. MatJafri, K. Abdullah, K. C. Tan, C. J. Wong, N. Mohd Saleh, Univ. Sains Malaysia (Malaysia)

$71140 \mathrm{U}$ An initial assessment of the CALIPSO lidar data on stratospheric aerosol backscatter coefficients over peninsular Malaysia [71 14-30]

A. N. Alias, M. Z. MatJafri, H. S. Lim, K. Abdullah, N. Mohd Saleh, Univ. Sains Malaysia (Malaysia)

7114 OV Merging of multi-temporal SST data at South China Sea [7114-31]

H. G. Ng, M. Z. MatJafri, K. Abdullah, H. S. Lim, Univ. Sains Malaysia (Malaysia)

Author Index 
Downloaded From: https://www.spiedigitallibrary.org/conference-proceedings-of-spie on 26 Apr 2023

Terms of Use: https://www.spiedigitallibrary.org/terms-of-use 


\title{
Conference Committee
}

\author{
Symposium Chair \\ David H. Titterton, Defence Science and Technology Laboratory \\ (United Kingdom) \\ Conference Chairs \\ Gary W. Kamerman, FastMetrix, Inc. (United States) \\ Ove K. Steinvall, FOI, Swedish Defence Research Agency (Sweden) \\ Keith L. Lewis, Electro Magnetic Remote Sensing Defence Technology \\ Center (United Kingdom) \\ Thomas J. Merlet, Thales S.A. (France) \\ Richard C. Hollins, Defence Science and Technology Laboratory \\ (United Kingdom) \\ Program Committee \\ Jeffrey W. Grantham, Northrop Grumman Corporation (United States) \\ Robert J. Grasso, BAE Systems (United States) \\ Dennis K. Killinger, University of South Florida (United States) \\ Vasyl V. Molebny, National Technical University of Ukraine (Ukraine) \\ C. Russell Philbrick, The Pennsylvania State University (United States) \\ Peter N. Randall, QinetiQ Ltd. (United Kingdom) \\ Philippe Réfrégier, Institut Fresnel (France) \\ Monte D. Turner, Defense Advanced Research Projects Agency \\ (United States) \\ Maria J. Yzuel, Universidad Autònoma de Barcelona (Spain)
}

\section{Session Chairs}

$1 \quad$ Passive Sensing and Data Processing

Gary W. Kamerman, FastMetrix, Inc. (United States)

2 EO Sensing Technologies and the EMRS DTC

Keith L. Lewis, Electro Magnetic Remote Sensing Defence Technology Center (United Kingdom)

Gary W. Kamerman, FastMetrix, Inc. (United States)

3 Laser Sensing and Systems

Ove K. Steinvall, FOI, Swedish Defence Research Agency (Sweden) 
4 Photonic Components and Architectures for Microwave Systems and Displays

Keith L. Lewis, Electro Magnetic Remote Sensing Defence Technology Center (United Kingdom) 